\title{
GAMBARAN PENGETAHUAN DAN SIKAP VULVA HYGIENE DALAM MENANGANI KEPUTIHAN (FLUOR ALBUS) PADA REMAJA PUTRI
}

\author{
Nisa Hanipah ${ }^{\mathbf{1}}$, Novita Nirmalasari ${ }^{2}$ \\ 1,2Universitas Jenderal Achmad Yani Yogyakarta \\ E-mail: nisahanipah74@gmail.com
}

\begin{abstract}
Adolescence is a transitional period with the maturity of the reproductive organs. Vaginal discharge (fluor albus) is a common reproductive health problem. This study aimed to determine the level of knowledge and attitudes of vulva hygiene in vaginal discharg (fluor albus) in female adolescent at SMKN 2 Godean Yogyakarta. This research was a descriptive quantitative study with a cross-sectional design. Samples were selected using random sampling. The number of samples was 68 with inclusion and exclusion criteria. The research instrument used a questionnaire. The data analysis used was univariate. Female adolescence experiencing vaginal discharge are at the age of 17 years (41.2\%), already menstruating (97.1\%), and experiencing vaginal discharge (97.1\%), good knowledge level (72.1\%) and positive vulva hygiene attitude (97,1\%). Most of the respondents had a good level of knowledge and positive vulva hygiene attitude.
\end{abstract}

Keywords: Fluor albus, Knowledge, Adolescent, Attitude

ABSTRAK: Masa remaja merupakan masa transisi dengan kematangan alat reproduksi. Keputihan (fluor albus) adalah masalah kesehatan reproduksi yang umum. Penelitian ini bertujuan untuk mengetahui tingkat pengetahuan dan sikap kebersihan vulva pada cairan vagina (fluor albus) pada remaja putri di SMKN 2 Godean Yogyakarta. Penelitian ini merupakan penelitian kuantitatif deskriptif dengan desain cross sectional. Sampel dipilih dengan menggunakan random sampling. Jumlah sampel 68 dengan kriteria inklusi dan eksklusi. Variabel penelitian ini adalah pengetahuan dan sikap vulva hygiene. Instrumen penelitian menggunakan kuesioner. Analisis data yang digunakan adalah univariat. Remaja perempuan yang mengalami keputihan adalah pada usia 17 tahun $(41,2 \%)$, sudah menstruasi $(97,1 \%)$, dan mengalami keputihan $(97,1 \%)$, tingkat pengetahuan baik $(72,1 \%)$ dan sikap kebersihan vulva positif $(97,1 \%)$. Sebagian besar responden memiliki tingkat pengetahuan yang baik dan sikap kebersihan vulva yang positif. Gambaran pengetahuan dan sikap vulva hygiene remaja putri dalam menangani keputihan sudah cukup baik dalam mencegah terjadinya keputihan.

Kata kunci: Fluor albus, pengetahuan, remaja, sikap,

\section{PENDAHULUAN}

Masa pubertas pada remaja putri terjadi karena perubahan dan peningkatan hormon $\mathrm{LH}$ (Luteinizing Hormone) dan FSH (FollicleStimulating Hormone), yang mengakibatkan kematangan pada bagian vagina (Sibagariang, 2016). Masalah yang sering dialami dan paling berisiko menjadi persoalan bagi seorang remaja putri adalah keputihan (Pradnyandari, Surya, \& Aryana, 2019).

Keputihan merupakan adanya sekret yang keluar atau cairan selain darah berlebihan dan tidak sewajarnya dari lubang vagina. Keputihan bisa terjadi baik secara normal (fisiologis) maupun abnormal (patologis) (Sukamto dkk, 2018). Faktor pencetus keputihan dapat disebabkan oleh bakteri, virus, jamur parasit, ataupun virus serta kurangnya kebersihan pada alat genetalia terutama vagina. Hal ini seperti jarang mengganti celana dalam maupun mengganti pembalut saat menstruasi, perawatan pada saat menstruasi yang kurang tepat, dan menggunakan celana yang tidak mudah untuk diserap keringat, serta hubungan seksual yang tidak sehat (Astuti, Wiyono, \& Candrawati, 2018).

Data Survei Kesehatan Reproduksi Remaja Indonesia (SKRRI) pada tahun 2010 menunjukan bahwa pada wanita usia 15-24 tahun rentan mengalami keputihan. Hasil penelitian memperlihatkan kejadian keputihan di Indonesia terjadi peningkatan setiap tahunnya hingga $70 \%$ dan didapatkan data sebanyak $50 \%$ remaja putri di Indonesia yang mengalami keputihan (Pradnyandari, Surya, \& Aryani, 2019).

Penelitian yang telah dilakukan menunjukkan bahwa sebanyak $52 \%$ santri memiliki personal hygiene habits yang buruk dan $48 \%$ memilki personal hygiene habits yang baik. Penelitian ini memaparkan bahwa sebanyak $75,5 \%$ santri mengalami fluor albus patologis dan $24,5 \%$ mengalami flour albus fisiologis (Nikmah \& Widyasih, 2018). Penelitian lain didapatkan bahwa pengetahuan buruk sebanyak $59,6 \%$ dan pengetahuan baik sebanyak 40,4\%, sikap buruk sebanyak 54,9\% dan sikap baik sebanyak $45,1 \%$. Penelitian ini juga menunjukkan perilaku buruk sebanyak 
$41,2 \%$ dan perilaku baik sebanyak $58,8 \%$, keputihan patologis positif sebanyak $28,4 \%$ dan keputihan patologis negatif sebanyak $71,6 \%$ (Sukamto dkk, 2018). Penelitian penelitian tersebut menujukkan masih rendahnya penegtahuan dan sikap terhadap penanganan keputihan pada remaja putri.

Prevalensi remaja putri yang mengalami keputihan masih cukup tinggi di Indonesia. Hal ini dapat disebabkan karena kurangnya informasi tentang keputihan. Remaja putri beranggapan bahwa keputihan merupakan hal yang wajar. Pengetahuan remaja tentang keputihan akan mempengaruhi sikap dan perilaku hidup bersih dan sehat (IImiawati \& Kuntoro, 2017). Tingkat pengetahuan tentang reproduksi berfungsi untuk mencegah terjadinya masalah pada organ reproduksi (Shadine, 2012).

Dampak dari keputihan yang tidak segera diobati dapat berakibat seperti terjadinya infeksi saluran reproduksi, infeksi menular seksual, radang panggul, dan salpingitis. Kasus PMS khususnya klamidia terjadi sekitar 6,2\% pada remaja usia 15-24 tahun. Perempuan yang mengalami keputihan yang disebabkan oleh infeksi berulang atau menahun dapat megalami infertil, tumor dan kanker serviks (Shadine, 2012).

Hasil studi pendahuluan telah dlakukan peneliti di SMK Negeri 2 Godean, Kabupaten Sleman. Sekolah sudah mempunyai program Usaha Kesehatan Sekolah (UKS) namun belum memilki pelayanan tentang organ reproduksi khususnya tentang keputihan. Hasil wawancara kepada 10 siswi di SMKN 2 Godean menyatakan bahwa semuanya sudah mengalami menstruasi dan pernah mengalami keputihan, serta sebagian besar sering mengalami keputihan. Didapatkan 8 siswi $(80 \%)$ yang belum mengetahui tentang keputihan, penyebab, tanda dan gejala. Sebanyak $2(20 \%)$ responden sudah tahu tentang keputihan tetapi belum paham tentang penyebab, pencegahan, ciri-ciri, dan tanda gejala dari keputihan. Menurut keterangan dari siswi, mereka belum pernah mendapatkan materi pembelajaran atau pendidikan kesehatan mengenai keputihan dan vulva hygiene di sekolah. Sebanyak 4 siswi $(40 \%)$ yang mengetahui cara membersihkan organ kewanitaan dengan benar dan 6 siswi $(60 \%)$ tidak mengetahui cara untuk membersihkan organ kewanitaan dengan benar.
Pengetahuan yang baik dan sikap yang baik akan berpengaruh pada pencegahan terjadinya keputihan. Program program yang sudah ada di sekolah perlu ditingkatkan lagi dalam pencegahan terjadinya keputihan. Penelitian yang telah dilakukan menunjukkan masih tingginya prevalensi keputihan di Indonesia. Hal ini menujukkan ketidakberhasilan dalam penanganan keputihan. Oleh karena itu, penelitian tentang pengetahuan dan sikap vulva hygiene perlu ditingkatkan. Hal ini sebagai upaya menentukan intervensi yang tepat dalam meningkatkan kualitas pelayanan kesehatan khususnya pada remaja putri. Harapannya penelitian ini dapat menjadi dasar penelitian-penelitian selanjutnya dalam hal menangani keputihan pada remaja putri.

\section{METODE PENELITIAN}

Penelitian ini merupakan penelitian deskripstif kuantitatif. Lokasi penelitian di SMKN 2 Godean. Pengambilan data dilakukan bulan Juni 2020 dengan teknik random sampling sebanyak 68 responden. Variabel dalam penelitian ini adalah pengetahuan dan sikap vulva hygiene. Alat pengumpulan data yang digunakan adalah lembar data karakteristik responden, kuesioner tingkat pengetahuan dan sikap vulva hygiene.

Uji Validitas dilakukan di SMKN 2 Godean dari 25 pertanyaan tingkat pengetahuan menjadi 23 pertanyaan yang dinyatakan valid, dan pertanyaan sikap vulva hygiene dari 14 pertanyaan didapatkan hasil 12 pertanyaan yang dinyatakan valid. Didapat $r$ tabel $=0,444$ ( $r$ hitung $>r$ tabel) Hasil uji reliabilitas kuesioner tingkat pengetahuan didapatkan nilai $\alpha=0,894$ yang berarti memiliki tingkat reliabilitas sangat baik (sempurna). Sedangkan hasil uji reliabilitas kuesioner sikap vulva hygiene didapatkan nilai $\alpha=0,782$ yang berarti kuesioner memiliki tingkat reliabilitas baik.

Data yang sudah terkumpul kemudian dila kukan editing, coding, entry data, processing dan cleaning. Analisis data yang digunakan yaitu analisis data deskriptif menggunakan ukuran sebaran data dalam frekuensi dan persentase.

\section{HASIL PENELITIAN}

Penelitian dilakukan pada 68 remaja putri di SMKN 2 Godean. Hasil penelitian disajikan pada tabel-tabel berikut : 
Tabel 1. Karakteristik Responden di SMKN 2 Godean $(n=68)$

\begin{tabular}{lcc}
\hline \multicolumn{1}{c}{ Karakteristik Responden } & Frekuensi (n) & Persentase (\%) \\
\hline Usia & 26 & $38,2 \%$ \\
16 tahun & 28 & $41,2 \%$ \\
17 tahun & 14 & $20,6 \%$ \\
$\quad 18$ tahun & 66 & \\
Riwayat keputihan & 2 & $97,1 \%$ \\
$\quad$ Ya & & $2,9 \%$ \\
$\quad$ Tidak & 66 & \\
Riwayat Menstruasi & 2 & $97,1 \%$ \\
$\quad$ Pernah menstruasi & $2,9 \%$ \\
Belum Pernah menstruasi & Total & $100 \%$ \\
\hline
\end{tabular}

Tabel 1 menunjukan bahwa usia 17 tahun lebih banyak yang mengalami keputihan dengan jumlah 28 remaja putri $(41,2 \%)$. Jumlah orang yang sudah mengalami menstruasi dan keputihan yaitu sebanyak 66 remaja putri $(97,1 \%)$.

Tabel 2. Tingkat Pengetahuan Vulva Hygiene dalam Menangani Keputihan di SMKN 2 Godean, Sleman $(n=68)$

\begin{tabular}{ccc}
\hline Tingkat Pengetahuan & Frekuensi (n) & Persentase (\%) \\
\hline Baik & 49 & $72,1 \%$ \\
Cukup & 15 & $22,1 \%$ \\
Kurang & 4 & $5,9 \%$ \\
\hline Total & 68 & $100 \%$ \\
\hline
\end{tabular}

Tabel 2 menunjukkan bahwa tingkat pengetahuan sebanyak 68 remaja putri sebagian besar baik yaitu sebanyak 49 remaja putri $(72,1 \%)$.

Tabel 3 Distribusi Responden Sikap Vulva Hygiene dalam Menangani Keputihan di SMKN 2 Godean, Sleman $(n=68)$

\begin{tabular}{ccc}
\hline Sikap Vulva Hygiene & Frekuensi (n) & Presentase (\%) \\
\hline Positif & 66 & $97,1 \%$ \\
Negatif & 2 & $2,9 \%$ \\
\hline Total & 68 & $100 \%$ \\
\hline
\end{tabular}

Tabel 3 menunjukkan bahwa sikap vulva hygiene dalam menangani keputihan sebagian besar positif yaitu 66 remaja putri $(97,1 \%)$.

\section{PEMBAHASAN}

\section{Karakteristik Responden}

Hasil penelitian menunjukkan responden terbanyak berumur 17 tahun dan responden yang terkecil berumur 18 tahun. Hal ini didukung oleh penelitian yang dilakukan oleh Putri (2016) menyatakan bahwa wanita lebih banyak mengalami keputihan yaitu pada usia 17 tahun yaitu sebanyak 11 remaja putri $(27,5 \%)$ dan paling sedikit pada usia 18 tahun yaitu sebanyak 6 remaja putri (15\%). Hasil penelitian berdasarkan usia menunjukkan bahwa usia remaja usia 15-18 tahun sangat rentan terhadap keputihan. Hal ini semakin bertambahnya usia maka hormon estrogen dan progesteron pada remaja perempuan akan meningkat. Hormon ini diproduksi oleh indung telur dan vagina akan tumbuh dan berkembang untuk melakukan fungsinya serta melakukan proses reproduksi yang ditandai dengan adanya menstruasi (Rohan \& Siyota, 2013).

Riwayat menstruasi pada hasil penelitian menunjukkan sebagian besar 
telah mengalami menstruasi yaitu sebanyak 66 remaja putri. Penelitian ini sependapat dengan (Savitri \& Astuti, 2019) bahwa sebagian besar sudah menstruasi yaitu sebanyak 93 remaja putri (100\%). Pada remaja perempuan akan mengalami perubahan yang dirangsang oleh hormon estrogen dan progesteron yang ditandai dengan adanya menstruasi (Kusmiran, 2012). Menurut Pratiwi (2012) bahwa keputihan fisiologis dapat dipengaruhi oleh perubahan hormon terutama pada saat siklus menstruasi yaitu pada hari ke 10-16. Pada saat menstruasi seorang remaja harus memperhatikan dan memerlukan praktik vulva hygiene dengan baik dan benar. Apabila tidak menjaga kebersihan maka akan menimbulkan infeksi jamur dan bakteri yang menyebabkan gatal-gatal pada organ kewanitaan dan terjadi keputihan (Hanissa, 2017)

Sebagian besar remaja putri di SMKN 2 Godean mengalami keputihan sejumlah 66 remaja putri. Hal ini sejalan dengan penelitian Rahmayanti \& Sulistyoningtya (2016) sebagian besar mengalami keputihan yaitu sebanyak 39 remaja putri $(83,0 \%)$ dan yang tidak mengalami keputihan yaitu sebanyak 8 remaja putri $(17,0 \%)$. Menurut Kusmiran (2012) keputihan merupakan secret atau cairan selain darah yang keluar secara berlebihan dari organ reproduksi perempuan yaitu vagina. Keputihan tidak selamanya merupakan penyakit (patologis) karena ada juga keputihan yang normal (fisiologis). Selain itu menurut Agustiyani (2015) kondisi stress dan kelelahan fisik maupun psikologis dapat memicu peningkatan hormon estrogen. Pengaruh hormon estrogen dapat menyebabkan terjadinya keputihan. Kondisi keputihan memerlukan penanganan segera agar tidak semakin parah dan menimbulkan komplikasi.

\section{Gambaran Tingkat Pengetahuan}

Hasil penelitian menunjukkan bahwa tingkat pengetahuan sebagain besar pada kategori baik. Hal ini sesuai dengan penelitian yang dilakukan oleh Februari (2016) menunjukkan bahwa sebesar 50 remaja putri $(61,7 \%)$ berpengetahuan baik, dan 22 remaja putri $(27,2 \%)$ berpengetahuan cukup, serta 9 remaja putri $(11,1 \%)$ memiliki pengetahuan yang kurang.
Salah satu faktor yang mempengaruhi dari hasil penelitian tersebut yaitu dengan adanya faktor pengetahuan yang mempengaruhi personal hygiene seseorang. Dampak dari keputihan yang tidak segera diobati dapat berakibat buruk bagi kehidupan seorang wanita terutama remaja seperti terjadinya infeksi saluran reproduksi, infeksi menular seksual, radang panggul, dan salpingitis. Penelitian lain yang dialkukan oleh Rakhmawati (2019) mengungkapkan bahwa sebagian besar responden sebanyak 82 responden $(67,5 \%)$ memiliki pengetahuan yang baik.

\section{Gambaran Sikap Vulva Hygiene}

Hasil penelitian diketahui bahwa sebagian besar remaja mempunyai sikap positif dalam menangani keputihan walaupun masih terdapat sikap yang negative. Hal ini sejalan dengan penelitian yang dilakukan oleh Februari, Astuti, \& Hartinah (2016) menunjukkan bahwa remaja sebagian besar memiliki sikap positif dalam menangani keputihan sebanyak 46 remaja putri $(56,8 \%)$ dan sikap negatif sebanyak 35 remaja putri $(43,2 \%)$. Penelitian lain yang dilakukan Gampu dkk (2018) menunjukkan bahwa terdapat sikap baik remaja putri sebesar 28 responden $(66,7 \%)$. Menurut Purwoastuti dan Walyani (2015) mengatakan bahwa apabila seorang remaja yang sering menggunakan antiseptik pada vagina secara berlebihan maka akan membunuh bakteri yang baik yang berfungsi untuk menjaga keasaman vagina dan dapat menyebabkan iritasi dan keputihan. Teori menyebutkan bahwa sabun tidak dianjurkan untuk pembersih vagina, karena sabun dapat mengubah tingkat keasaman dan dapat membunuh bakteri endogen yang ada pada vagina. Menurut Rakhmila (2016) sikap merupakan respon pribadi terhadap rangsangan atau objek spesifik yang melibatkan opini atau emosi pribadi. Faktor yang mempengaruhi sikap yaitu pengalaman pribadi, efek eksternal, budaya, media, lembaga pendidikan, dan masalah emosional.

\section{KESIMPULAN DAN SARAN}

Gambaran tingkat pengetahuan remaja putri dalam menangani keputihan sebagian besar memiliki pengetahuan yang baik dan sikap vulva hygiene remaja putri 
mayoritas memiliki sikap yang positif. Sekolah sebaiknya memberikan penyuluhan tentang organ reproduksi bagi siswasiswinya sehingga dapat mencegah

\section{DAFTAR PUSTAKA}

Agustyani, Dwi. Hubungan Tingkat Stres dengan Kejadian Keputihan pada Siswi Kelas X dan MAN XI di SMA Taman Jetis Yogyakarta. Naskah Publikasi.Yogyakarta: Universitas Aisyiyah Yogyakarta. 2015.

Astuti, H., Wiyono, J., \& Candrawati, E. Hubungan Perilaku Vaginal Hygiene dengan Kejadian Keputihan pada Mahasiswi di Asrama Putri PSIK UNITRI Malang. Nursing News. 2018; 3(1), 595- 602.

Febryary, D.R., Astuti, S., Hartinah.Gambaran Pengetahuan, Sikap dan Perilaku Remaja Putri dalam Penanganan Keputihan di Desa Cilayung. Jurnal Sistem Kesehatan. 2016; 2 (1).

Gampu, H.T.H, Onibala, F., \& Kundre, R. Hubungan Sikap dan Pengetahuan Remaja Putri dengan Pencegahan Keputihan di SMA 3 Tahuna Barat Kabupaten Lumajang. E-Journal Keperawatan. 2018; 6(1), 1-8

Hanissa J., Nasution A.m\& Asri M.A. Gambaran Perilaku Personal hygiene Menstruasi Remaja Putri Yang Mengikuti Pelatihan dan Pembinaan PKPR Di SMP PGRI 13 Wilayah Kerja Puskesmas Sindang Barang Kota Bogor. Hearty Jurnal Kesehatan Masyarakat. 2017; 5(2)

Ilmiawati, H., \& Kuntoro. Pengetahuan Personal hygiene Remaja Putri pada Kasus Keputihan. Jurnal Biometrika dan Kependudukan. 2016;5(1), 4351.

Kusmiran, E. Kesehatan Reproduksi Remaja dan Wanita. Jakarta: Salemba Medika. 2012.

Nikmah, U. S., \& Widyasih, H. (2018). Personal Hygiene Habits dan Kejadian Fluor Albus Patologis pada Santriwati PP Al-Munawwir Yogyakarta. MKMI, 14(1), 36-43.

Pradnyandari, I. A., Surya, I. G., \& Aryana, M. B. Gambaran pengetahuan, sikap, dan perilaku tentang vaginal hygiene terhadap kejadian keputihan penyakit yang dapat ditimbulkan dari ketidakpedulian terhadap organ reproduksinya.

patologis pada siswi SMA Negeri 1 Denpasar periode Juli 2018. Intisari Sains Medis. 2019; 10(1), 88-94.

Purwoastuti, E., \& Walyani, E. S. Panduan Materi Kesehatan Reproduksi dan Keluarga Berencana. Yogyakarta: Pustaka Baru Press. 2015.

Putri, Y. R. Hubungan antara pengetahuan personal hygiene genetalia dengan kejadian keputihan pada remaja akhir di Indekost Tehel BiruPontianak.Jurnal Proners.2016; 3(1).

Rakhmawati D., Hubungan Tingkat Pengetahuan Remaja Putri tentang Vulva Hygiene Dengan Kejadian Keputihan pada Kelas XI di MAN Lumajang Kabupaten Lumajang. MID-Z Jurnal. 2019; 1(1), 45-52

Rakhmilla, L.E., Fah, L.I., Sofiatin, Y., Widjajakusuma, A., \& Rosyada, N.A. Knowledge, Attitude, and Practice about vaginal Discharge on SchoolAge Girls in Jatinangor Senior High School. Open Access Library Journal. 2016; 3, 1-9.

Rohan, H. H., \& Siyoto, R. Buku Ajar Kesehatan Reproduksi. Yogyakarta: Nuha Medika. 2013

Savitri, E, N., Astuti, D, A., Hubungan Tingkat Pengetahuan Tentang Vulva Hygiene dengan Kejadian Keputihan pada Siswi Kelas XI di MAN 1 Sleman.Naskah

Publikasi.Yogyakarta: Universitas Aisyiyah Yogyakarta. 2019

Shadine, M. Penyakit Wanita. Yogyakarta: Citra Pustaka Yogyakarta. 2012

Sibagariang, E. E. Kesehatan Reproduksi Wanita. Jakarta Timur: Trans Info Media. 2016

Sukamto, N. R., Yahya, Y. F., Handayani, D., Argentina, F., \& Liberty, I. A. Hubungan Pengetahuan, Sikap, dan Perilaku Perawatan Vagina terhadap Kejadian Keputihan Patologis pada Mahasiswi Program Studi Pendidikan Dokter Fakultas Kedokteran Universitas Sriwijaya. Majalah Kedokteran Sriwijaya. 2018;(4), 